\title{
Contribution of social support co-workers and social self concept to conditions of school counselor burnout
}

\author{
Suci Habibah ${ }^{1}$, Herman Nirwana $^{2}$, Afdal $^{3}$ \\ ${ }^{123}$ Universitas Negeri Pada \\ ng, Padang - Indonesia, (sucihabibah09@gmail.com)
}

\begin{abstract}
This study aims to examine the contribution of social support co-workers and social selfconcepts together to school counselor burnout conditions. This research uses quantitative method of correlation descriptive type. The population of the research is the State Senior High School counselor of Pekanbaru City. The sample numbered 52 people school counselors were assigned with sampling technique total sampling. The instruments used are the "Burnout Scale" with reliablity 0,976, "Social Support Co-workers Scale" with reliability 0,959, and "Social Self-Concept Scale" with reliablity 0,934. The research data were analyzed using multiple regression. The research findings show that there is contribution of social support of co-workers and social self concept to burnout condition equal to $55.7 \%$. The implications of this research on guidance and counseling will be discussed.
\end{abstract}

Keywords: social support co-workers, social self-concept, burnout.

\section{Introduction}

School counselors have an important role in helping students to achieve their developmental tasks with all their abilities. Zikra, Sukmawati \& Afdal (2016) explains that school counselors are required to be professionals in their field, the current growing expectations of school counselors are in spiteful schools, out of school steady, everywhere ready. This suggests that school counselors should be placed anywhere in accordance with what areas they have. In addition, Afdal (2015) explains that collaboration activities with various parties (including with parents) is important to be done by the counselor in order to achieve the goal of optimal counseling and guidance services. The number of tasks performed by school counselors to make school counselors experience fatigue, stress and often lead to burnout conditions. Furthermore, some research results suggest that school counselors have the possibility to get burnout. This is in line with the opinion of Corey \& Corey (in Fernet, Guay, Caroline, \& Austin, 2012) explains that school counselors who are overworked in dealing with clients will experience emotional fatigue that will lead themselves to the condition of fatigue.

The next, (Fernet, Guay, Caroline, Austin, 2012; Kiarie, Sirera, \& Mwenje; 2011) explains that the teaching profession is more susceptible to burnout than other professions. Wozny, Polowczyk \& Zygmunt (2014) found that $54 \%$ of teachers feel stressed out with their work. Furthermore, the results of research by Schonfeld \& Bianchi (2016) explain $86 \%$ of teachers identified burnout also experienced depression conditions. Based on some of the above results it is known that the BK Teachers 
experience a stressful condition that if this continues to be left then will deliver the teacher on the condition of burnout. Chernis (1980) describes burnout as a change of attitude and behavior in the form of psychological withdrawal from work, such as keeping the distance with clients and being cynical with them, ditching, often late, and the desire to move strong work. Based on the above opinion, it can be concluded that burnout is a condition of physical, emotional and mental fatigue that makes a person behave psychologically withdraw from work in response to excessive stress. Burnout is also interpreted as a depressed condition in work or lose spirit in doing the job. Maslach \& Leiter (1997) suggests three dimensions of burnout: (1) exhaustion experienced by a person at work can cause a person to feel things overload, both emotionally and physically, (2) cynicism (cynicism) which makes a person take a cold and distant attitude toward the work, and the people around him, (3) ineffectiveness is an ineffective feeling, feeling less and less capable of doing the job.

Based on interviews with 5 school counselors from several high schools Pekanbaru on February 6 \& 7, 2017 it was found that school counselors often felt headaches after coming home from school, disrupted appetite, while facing students sometimes less able school counselors to control emotions such as anger and snarling in providing counseling services, school counselors feel underprivileged while performing their duties, finding it difficult to work with some of the subject teachers who demand a change of child in the immediate aftermath of counseling. For school counselors the number of students is not proportional to the number of school counselors available, feeling saturated with negative judgments about guidance and counseling performance. school counselors feel bored with the same student problems. Based on the above interviews it can be concluded that school counselors are beginning to show symptoms of burnout with fatigue, decreased energy, physical distress such as headache, difficulty eating, tend to be indifferent, keep a distance from work, and feel cynical with others. Burnout is influenced by several factors. Maslach and Leiter (1997) explain that the causes of burnout can be seen from six forms of nonconformity between people and their work: workload, lack of system control, inadequate rewards, disruption of community system in work, loss of justice, and value conflict. Furthermore, Gold and Roth (1993) suggested factors affecting burnout among teachers; lack of social support, demographic factors, self-concept, role of conflict (role of ambiguity), and isolation.

Based on the above opinion there are several factors that affect burnout one of them social support. Social support is needed by school counselors to prevent burnout, with the social support of school conselors is better able to strengthen themselves in the face of stressful situations in work and able to overcome the existing problems. Taylor, Peplau, and Sears (2009) argue in the face of pressing events, individuals need social support. Individuals with high social support can cope with stress more successfully than those with less social support. Fraizer (in Baron and Byrne, 2002) explains that social support is very useful to help a person in dealing with stressful conditions. Ganster, Fusilier, and Mayes (1986) argue that sources of social support can come from family, co-workers, and superiors. Furthermore, Barak, Nissly, and Levin (2001) also explained that the lack of social support had a negative impact on teachers in dealing with stress on the job. This is also supported by the Adawiyah (2013) study that there is a very significant negative relationship between social support and burnout tendencies. From the above explanation it can be seen that the social support of coworkers is a factor affecting the condition of school counselors burnout.

Factors that cause burnout conditions not only lack of social support, but also there are other factors that become sources of someone experiencing burnout one of them is self concept. Self-concept is necessary for someone to avoid burnout. Maslach (in Schaufeli, Maslach, \& Marek, 1993) suggests that individuals who have a negative self-concept are susceptible to burnout conditions, characteristic of individuals who have negative self-concepts that are not confident and have low self-esteem. Strang (in Mudjiran, 2007) argues that social self-concept is a person's opinion of the quality of himself, how others view him or her social ability, social success, this can increase individual confidence and will develop positive self-concept. 
The results of Rad \& Nasir (2010) explains that self-concept plays an important role in work, feelings and behavior. teachers who have a positive self-concept about themselves will experience fewer symptoms of stress and burnout. In line with research conducted by Howard (in Rad \& Nasir 2010) found that individuals with high burnout tend to have a negative self-concept. Based on the phenomenon and data above, it was revealed that there are symptoms of school counselors starting to experience Burnout in performing their duties as school counselors. therefore the researchers feel the need to conduct research to examine and analyze in depth about factors related to the condition that is the contribution of social support co-workers and social self-concept of the condition of school counselor burnout.

The purpose of this research is to know the description of social support co-workers, social self concept and burnout condition. The next objective is to find out the amount of social support contribution of co-workers and social self-concept of burnout condition. The results of this study can be used as a tool for stakeholders to work together to overcome and prevent burnout conditions in school counselors.

\section{Method}

This research uses quantitative approach with correlational descriptive type. Population this research is all counselor of high school of Pekanbaru which number 52 people. The sample in this research is 52 school counselors. The sample is determined by the total sampling technique or the saturated sample. The instrument used is "Burnout Scale" with reliability 0.976, "Social Support Scale of Workers" with 0.959 reliability, "Social Concept Scale" with reliability 0.934 . With Likert scale model. To know the contribution of independent variable to dependent variable, then the data is analyzed by multiple regression. Data analysis was assisted by using SPSS program version 20.00.

\section{Results and Discussion}

\section{Social Support Contribution of Co-Worker and Social Self Concept of School Counselor Burnout Condition}

The results of the analysis show that social support of co-workers and social self-concept contribute negatively to the burnout condition. Result of contribution social support of co-worker and social self concept of school counselor burnout condition can be seen in table 1. Results of Coefficient Regression Test Social Support Co-Worker and Social self concept of school counselor burnout.

\section{Table 1.}

Results of Coefficient Regression Test Social Support Co-Worker and Social Self Concept Of School Counselor Burnout.

\begin{tabular}{llll} 
Variabel & $\mathbf{R}$ & R Square & Sig. \\
$\mathrm{X}_{1} \mathrm{X}_{2}-\mathrm{Y}$ & $-7,747$ & 0,557 & 0.000 \\
\hline
\end{tabular}

Table 1 shows the $\mathrm{R}$ value of -0.747 , which shows coefficient regression of social support of coworkers and social self-concept of burnout condition. R Square value of 0.557 , means $55.7 \%$ of social support co-workers and social self-concept of burnout condition, with a significance level of 0.000 . The results of the analysis show that social support of co-workers and social self-concept contribute negatively to the burnout condition. That is, the higher the social support of co-workers and social self-concept, the lower the burnout condition of school counselors, or vice versa. Therefore, to reduce the condition of school counselor burnout then one way to increase social support co-workers and social self-concept on school counselor. 
The analysis results have been described, that the social support variables of co-workers and social self-concept can be used to predict the burnout condition variable. In the following sections we will explain the discussion for each variable. Social Support Contribution and Social Concept of School Counselor Burnout Condition. The results showed that social support co-workers and social selfconcepts together contribute significantly to the condition of school counselor burnout. This finding is obtained based on the series of data analysis that the regression coefficient of -0.747 . The coefficient of determination (R Square) of social self concept and social support of colleagues collectively to the condition of burnout of school counselor is 0.557 . That is, the contribution of social support variables of co-workers and social self-concept together to the condition of burnout school counselors $55.7 \%$, while the rest $(100 \%-55.7 \%=44.3 \%)$ is explained by other variables not examined in this study. It is revealed that social support co-workers and social self-concepts together can be a factor that influences the condition of school counselor burnout.

The mutual contribution of the social support of co-workers and social self-concept due to the interaction between the two variables. If school counselors have high social support, and have a positive social self-concept, then school counselors will tend to have low burnout conditions. Vice versa, if school counselors get low social support from co-workers and have negative self-concept, then school counselors will tend to have high burnout conditions. If one of the social support variables is high co-worker and social self-concept is low, it will be able to reduce burnout condition. Thus, the deficiencies in one variable will be offset by the surplus of other variables. Therefore, the relationship between the two variables together with the condition of school counselor burnout, because of the interaction between the two variables. The factors that affect the condition of burnout in school counselors according to Gold \& Roth (1993) are as follows: 1) lack of social support, 2) demographic factors (demographic factors), 3) self-concept self), 4) role conflict and role ambiguity (role conflict and role ambiguity), 5) isolation (isolation).

Schaufeli \& Greenglass (2001) explains that social support will be able to reduce fatigue because it can provide important information, and emotionally beneficial to workers. Laily (2011) explains that the condition of fatigue in work can happen or not depends on how big the individual worker educators view the work environment and social support that exist within the organization. Similarly, Barak's study, Nissly, \& Levin (2001) explains that lack of social support negatively impacts teachers and their ability to cope with stress in work. Adawiyah (2013) explains there is a very significant negative relationship between social support and burnout tendencies. Those with high social support are less likely to experience burnout in work. Furthermore, Kwook \& Wai (in Ibrahim, 2014) explain that social support can have a positive effect on psychological well-being.

Sarafino \& Smith (2011) explains that individuals who receive social support believe that they are loved, valued and a part of social networks (such as family, community or organization) and assume that they can get the necessary help whenever from other people or social networks. Furthermore, Hadipranata (1999) describes supportive colleagues will create a helpful, friendly and cooperative situation that will create a pleasant work environment and can lead to satisfaction in work and avoid saturation in work.

The next factor that affect the condition of burnout is self concept. This is in line with the results of research Rad \& Nasir (2010) explains there are significant differences in saturation and career selfconcept between male and female teachers. Furthermore, it was found that there was a negative correlation between career self-concept and burnout. In line with research conducted by Howard (in Rad \& Nasir 2010) found that individuals with high burnout tend to have a negative self-concept.

Negative social self-concept negatively affects people's behavior that will affect their lives, such as work and interaction with others. Thus, school counselors are vulnerable to burnout if they have a negative self-concept. This is in line with Dembo's opinion (in Kraebber \& Greenan, 2012) states that positive self-concept is important for all individuals, because self-concept is a person's ideas or 
perceptions about himself. Self-concept has a big influence on the behavior displayed by the individual, if the self-concept of positive individuals will be born a positive pattern of behavior.

Furthermore, Gold \& Roth (1993) explains that individuals who have a positive self-concept more able to cope with stress and more able to maintain a sense of self-esteem when under pressure. One often feels that self-esteem and sense of belonging will have an influence when one feels disappointed and discouraged. Maslach (in Schaufeli, Maslach, \& Marek, 1993) suggests that individuals who have a negative self-concept are susceptible to burnout conditions, characteristic of individuals who have negative self-concepts that are not confident and have low self-esteem. It explains that positive social self concept is very important for BK Teachers to be able to improve all the potential that is in him and able to interact with other people in the work environment or daily life.

The results of Amelia \& Zulkarnain (2005) explains that there is a role of self-concept to the level of burnout. Therefore, employees can make self-concept as the basis and benchmark in reducing burnout level. As for ways to improve self-concept among others is more to know who we are and the potential that exists within ourselves also the deficiencies that exist within us, putting the expectations in accordance with the abilities that exist on it, and always respect themselves. So that burnout can be avoided.

Based on the above explanation reinforce, that there are several factors that can give effect to the condition of burnout, such as social support co-workers and social self-concept. Furthermore from the results of hypothesis testing, presumably can be a reference for Teacher BK in overcoming the burnout condition.

\section{Conclusions}

This research can be concluded that school counselors have an important role in helping students to achieve the development tasks it has. The number of tasks performed by school counselors makes it vulnerable to burnout conditions. this study explains that social support of co-workers and social self-concept contribute to the condition of school counselor burnout. Therefore, to reduce the condition of school counselor burnout then it needs to be improved social support co-workers and social self-concept. If the social support of co-workers and social self-concept is increasing then it will reduce the burnout condition of school counselors.

Therefore, school counselors are expected to develop positive self-concept and improve the quality of social relationships with colleagues in order to social support colleagues who can help school counselors overcome the problems encountered in working with stress management training, group discussions, MGBK and discussion other professionals, familiarize the cooperation among teachers, implement a gathering program that can tie the relationship between teachers, and create a competitive and harmonious relationship. So with the comfort and atmosphere conducive school counselors are expected to cope and prevent the occurrence of burnout conditions. in addition, the principal is expected to maximize his role in guidance counseling and counseling services so that school counselors avoid burnout conditions.

\section{References}

Adawiyah, R. A. R. (2013). Kecerdasan Emosional, Dukungan Sosial \& Kecenderungan Burnout. Pesona Jurnal Psikologi Indonesia, 2(2), 99-107.

Afdal, A. (2015). Kolaboratif: Kerangka kerja konselor masa depan. Jurnal Konseling dan Pendidikan, $3(2), 1-7$. 
Amelia, R., \& Zulkarnain, Z. (2005). Konsep Diri dan Tingkat Burnout pada Karyawan yang Bekerja di Instansi Pelayanan Masyarakat. Psikologika: Jurnal pemikiran dan penelitian psikologi, 10(19), 4149.

Astarini, D., Nirwana, H., \& Ahmad, R. (2016). Hubungan antara Konsep Diri Sosial, Persepsi Siswa tentang Dukungan Sosial Orangtua, dan Teman Sebaya dengan Komunikasi Interpersonal Siswa dan Implikasinya terhadap Pelayanan Bimbingan dan Konseling. Konselor, 5(4), $247-257$.

Barak, M., Nissly., \& Levin. (2001). Antecedents to Retention and Turnover among Child Welfare, Social Work, and Other Human Service Employees: What can we learn from past research? a review and metanalysis. The Social Service Review, 75(4), 625-661.

Baron, R. A., \& Byrne, D. (2002). Psikologi Sosial Jilid 1. Terjemahan oleh Ratna Djuwita. Jakarta: Bumi Aksara.

Bataineh, O., \& Alsagheer, A. (2012). An Investigation of Social Support And Burnout among Special Education Teachers in the United Arab Emirates. University of Sharjah, 27(2), 5-13.

Blazer, C. (2010). “Teacher Burnout”. Information Capsule Research Services Office of Assesment, Research, and Data Analysis, 1003, 1-19.

Burns, R. B. (1993). Konsep Diri Teori, Pengukuran, Perkembangan, dan Perilaku. Terjemahan oleh Eddy. Jakarta: Arcan.

Cherniss, C. (1980). Staff Burnout: Job stress in the human services. London: Dage Publications

Fernet, C., Guay, F., \& Austin, S. (2012). Predicting Intraindividual Changes in Teacher Burnout: The role of perceived school environment and motivational factors. Journal Teaching and Teacher Education, 28, 514-525.

Ganster, D. C., Fusilier, M. R., \& Mayes, B. T. (1986). Role of Social Support in The Experience of Stress at Work. Journal of Applied Psycholog, 71, 102-110.

Gold. Y., \& Roth, R. A. (1993). Teachers Managing Stress and Preventing Burnout: The professional health solution. London: The Flamer Prees.

Gunduz, B. (2012). Self Efficacy and Burnout in Professional School Counselors. Mersin University, 12(3), 1761-1767.

Herr, E. L., \& Cramer, S. H. (1984). Career Guidance and Counseling Through the Life Span. Boston: Little Brown Company

Kiarie, J. M., Sirera, A., \& Mwenje, M. (2011). The Effect of Burnout on Teacher Counselors Work Engagement. Kenyan Journal of Guidance, Counseling and Psychology, 1(1), 24-37.

Laily, N. (2011). Burnout Tenaga Pendidik Wanita Ditinjau dari Lingkungan Kerja Psikologis dan Dukungan Sosial. Prosiding Seminar Nasional \& Internasional, 1(1), 92-100.

Maslach, C., \& Leiter, M, P. (1997). The Truth About Burnout. San Francisco: Jossey Bas.

Mudjiran. (2007). Perkembangan Peserta Didik: Bahan pembelajaran untuk tenaga kependidikan sekolah menengah. Padang: UNP Press.

Purba, J., Yulianto, A., \& Widyanti, E. (2007). Pengaruh Dukungan Sosial terhadap Burnout pada Guru. Jurnal Psikologi, 5(1), 77-87.

Rad, A. Z., \& Nasir, R. (2010). Burnout and Career Self Concept among Teachers in Mashhad, Iran. Procedia Social and Behavioral Sciences. Universiti Kebangsaan Malaysia, 7(C), 464-469.

Sarafino, E. P., \& Smith, T. W. (2011). Health Psychology: Biopsychosocial interactions. Hoboken: Jhon Willey dan Sons, In

Schaufeli, W. B., Maslach, C., \& Marek, T. (1993). Profesional Burnout: Recent developments in theory and research. Washington DC: Routledge the Taylor \& Francis Group.

Schonfeld, I. S., \& Bianchi, R. (2016). Burnout and Depression: Two enities are one?. Journal of Clinical Psychology. 72(1), 22-37.

Taylor, S. E., Peplau., \& L. A., Sears, D.O. (2009). Psikologi Sosial (edisi ke dua belas). Jakarta : Kencana Prenada Media Group.

Undang-undang Nomor 20 Tahun 2003 tentang Sistem Pendidikan Nasional. Jakarta: Kementerian Pendidikan Nasional. 
Wiyono, Y. (2014). Peran Pemimpin, Rekan-Kerja, dan Keluarga dalam Memotivasi Karyawan di Pt Mulya Adhi Paramita Surabaya. Agora, 2(1), 368-378.

Wood, J. T. (2010). Interpersonal Communication: Everyday encounters (Sixth Edition). Boston: Cengage Learning.

Wood, J. T. (2013). Komunikasi Teori dan Praktik: Komunikasi dalam kehidupan kita. Terjemahan oleh Putri Alia Idris. Jakarta: Salemba Humanika.

Wozny, K. W., Polowczyk, L. S., \& Zygmunt, A. (2014). "Stress in the Teaching Profession". Journal of Education, Health and Sport, 5(6), 191-210.

Zikra., Sukmawati., \& Afdal. (2016). Burnout pada Konselor: Konsep dasar dan cara mengatasinya. Procedding International Counseling Seminar, 540. 